\title{
大阪大学基礎工学部化学応用科学科質量分析室と 「質量分析技術者近畿ブロック研究会」の紹介
}

\author{
Mass Analytical Division, \\ Department of Chemical Science and Engineering, \\ School of Engineering Science, Osaka University, \\ and The Study Group of Mass Spectrometry Technical Specialists in Kinki-Area
}

\author{
三宅里佳・戸部義人 \\ Rika Miyake and Yoshito Tobe \\ 大阪大学基礎工学部 - 基礎工学研究科
}

\section{1.はじめに（三宅里佳）}

日本質量分析学会の皆様はじめまして. 大阪大学基礎工学部で技術職員として質量分析を担当しております三宅里佳と 申します．質量分析の仕事歴は二十数年を数えますが，大阪大学に移りまだ 3 年目，気分も新たに仕事をさせていただい ています，大阪大学基礎工学部化学応用科学科質量分析室について紹介の任を仰せつかりましたが，何分にも日が浅いの で，当室の管理責任者である基礎工学研究科の戸部義人教授にこれまでの歴史について執筆のご協力をお願いいたしまし た．この機会に当室の紹介と併せて「質量分析技術者近畿ブロック研究会」について紹介させていただきます.

\section{2. 大阪大学基礎工学部質量分析室の歴史（戸部義人）}

基礎工学部は昭和 36 年に「科学と技術の融合による科学技術の根本的な開発それにより人類の真の文化を創造する学 部」を理念として設立された学部です. 設立時に合成化学科が, 昭和 38 年には化学工学科が設置され, この 2 学科が化学 教室として基礎工学部の化学系の教育研究とその運営を行ってきました. その後の大学院重点化や大学院の改組を経た後 も, これらの 2 学科が化学系教室として協力しつつ化学にかかわる教育研究を担当しています. 基礎工学部の質量分析室 独自の記録を保存していないため正確な歴史を記すことはできませんが，関係の諸氏からいただいた資料や情報をもとに してその概要を紹介します。

質量分析室は, 昭和 43 年に大学の特別設備費で日立の RMS-4型質量分析計（写真1）が導入されたのがきっかけとなっ て設置されました．昭和 45 年に技官に採用された福田和夫氏が質量分析の担当になり，分析室が本格的な活動を始めま した．福田氏は，定年退職されるまで 43 年にわたり質量分析と分析室の管理運営に尽力され，基礎工学部の化学系の発 展と日本質量分析学会に大きな貢献をされました。その業績か評価され，福田氏は平成19年度の日本質量分析学会の功 績賞を受賞されています。

当初導入されたRMS-4型質量分析計は主に気体試料を対象とする装置であったため, 福田氏が資料導入部に改良を加え て直接試料導入装置を設置することにより，液体・固体試料の分析が可能となりました。昭和 62 年に日本電子JMS-DX303HF型質量分析計（写真2）が導入され，FAB法やFD法によるイオン化が可能となり，測定可能な試料が分子量や物性 の両面から飛躍的に拡大しました。またFAB法による高分解能測定が標準分析として行えるようになり，特に化学教室の 有機化学系の研究を支える大きな力になりました．平成 13 年には大型プロジェクトで導入された後共用になった日本電 子JMS-700型質量分析計（写真3）が利用可能となり, 従来のイオン化法に加えてESI法, ナノ-ESI法か加わることで, 質 量分析技術がさらに充実しました。福田氏の定年退職後, 平成26年度からは三宅里佳氏が技術職員として着任しました。 設置後 15 年以上を経たJMS-700型質量分析計にメンテナンスを施すことで高性能を維持するとともに，研究者・学生との 対話を通じてきめ細かな研究支援をしていただいています。

連絡先：miyake@chem.es.osaka-u.ac.jp 


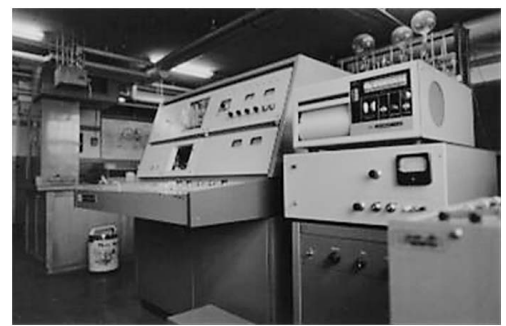

写真1. 日立RMS-4型質量分析計.

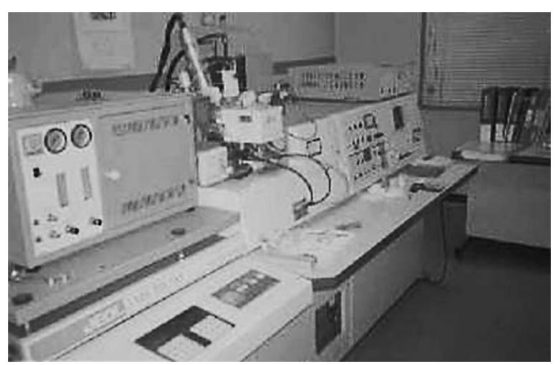

写真2. 日本電子JMS-DX303HF型質量分析計.

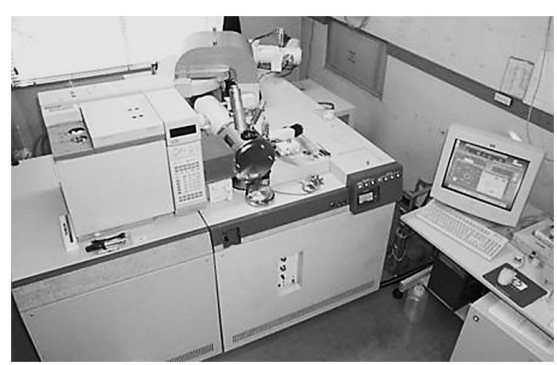

写真3. 日本電子JMS-700型質量分析計.

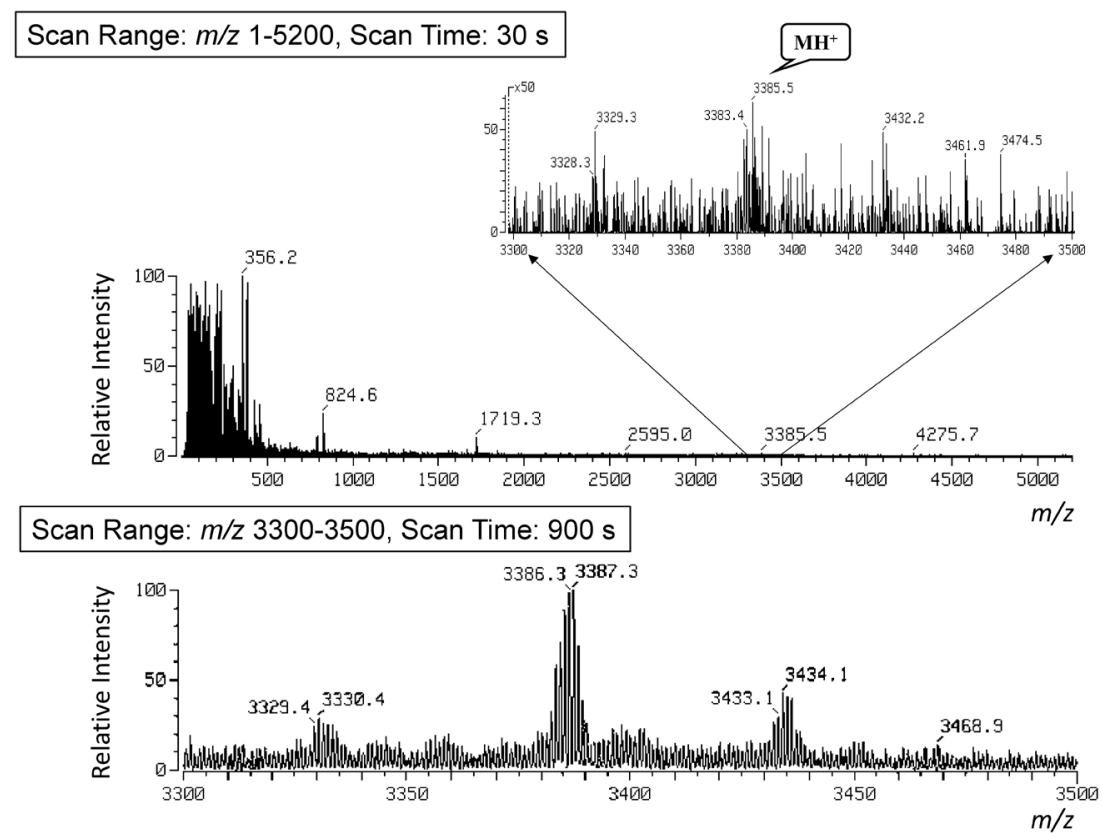

Fig. 1. スキャン速度の変化に伴うマススペクトルの変化. デンドリマー試料の FABマススペクトル．測定条件，加速電圧： $5 \mathrm{kV}$; 設定分解能：5000（10\%谷）； FABエネルギー：6 keV, $1 \mathrm{~mA}$ ；スキャン法：磁場スキャン法.

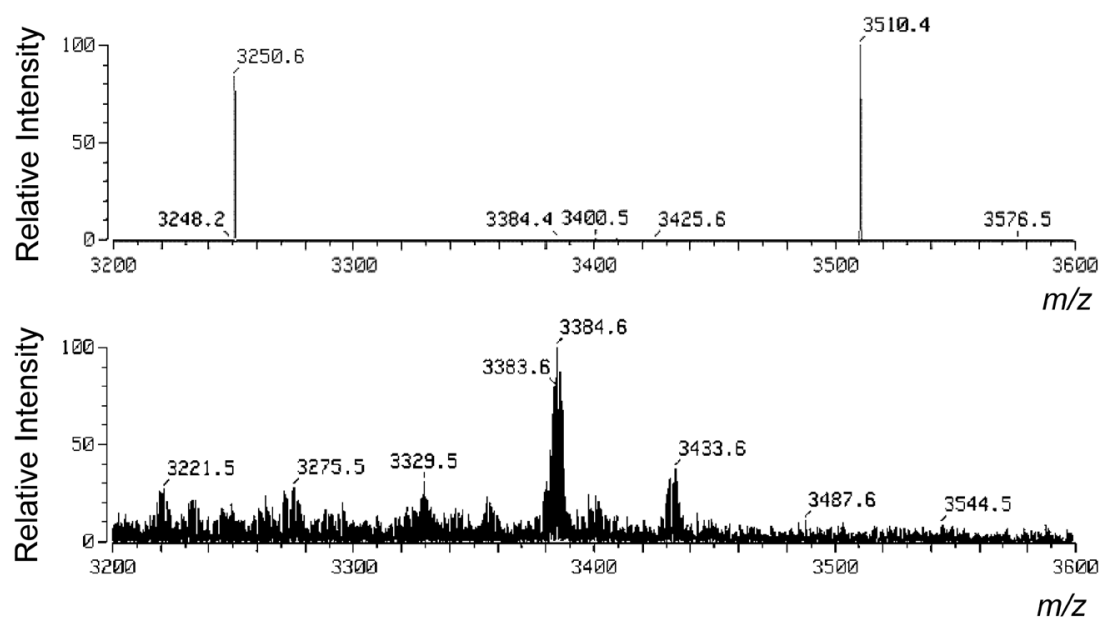

$\begin{array}{cccc}\text { Observed mass }\left(\mathrm{MH}^{+}\right) & \text {Error } & \text { Composition } & \text { Calculated mass } \\ 3383.5769 \mathrm{Da} & 0.3 \mathrm{mDa}, 0.1 \mathrm{ppm} & \left({ }^{12} \mathrm{C}_{184}{ }^{1} \mathrm{H}_{304}{ }^{14} \mathrm{~N}_{62}\right)^{1} \mathrm{H}^{+} & 3383.5766 \mathrm{Da} \\ 3384.5808 \mathrm{Da} & 0.8 \mathrm{mDa}, 0.2 \mathrm{ppm} & \left({ }^{12} \mathrm{C}_{183}{ }^{13} \mathrm{C}_{1}{ }_{1} \mathrm{H}_{304}{ }^{14} \mathrm{~N}_{62}\right)^{1} \mathrm{H}^{+} & 3384.5800 \mathrm{Da}\end{array}$

Fig. 2. デンドリマー試料の精密質量測定の結果. 上：CsI，下：デンドリマー試料。測定条件，スキャン範囲： $m / z \quad 3200 ３ 600$ ； スキャン時間： 120 秒; 加速電圧： $5 \mathrm{kV}$; 設定分解能：5000（10\%谷）； $\mathrm{FAB}$ エネルギー：6 keV, $1 \mathrm{~mA}$; スキャン法：加速ス キャン法. 


\section{3. 現在の質量分析装置を用いた分析の紹介（三宅里佳）}

現在設置されている装置は，日本電子JMS-700型質量分析計1台です．磁場型装置でイオン化法は， EI, CI, FAB, FD, ESI 法での測定が可能です．測定試料は主に化学合成物で合成確認が目的ですので，マススペクトルの取得と精密質量測定の両 方を行う場合が多いです．試料の分子量は 100 程度から 5,000 位と幅がありますが，分子イオンやプロトン付加分子の確認や その精密質量測定を難なく行えますが，中にはちょっと工夫の要る試料も存在するので，紹介させていただきます．

普段行っている磁場スキャン法を用いた速いスキャンでは, 痕跡程度のピークしか確認できない試料でも, 測定範囲を 絞りゆっくりスキャンすると同位体パターンまでしっかり確認できます ${ }^{1)}$ (Fig. 1). 測定時間は少し必要となりますが，き れいなスペクトルを得ることができます。マトリックスにはすべて3-Nitrobenzylalcoholを用いました.

次に，同じ試料の精密質量測定を行った結果を示します（Fig. 2)。標準試料にヨウ化セシウム（CsI）を用い，試料導 入はプローブ抜き差し法を用いて行いました。精度良い測定結果を得ることができました。

\section{4. 「質量分析技術者近畿ブロック研究会」の立ち上げとこれまでの活動（三宅里佳）}

平成18年に質量分析に携わる技術職員のスキルアップを目指し，近畿圈の大学および大学共同機関などで質量分析に かかわっている技術職員の方々に声をかけ，「質量分析技術者近畿ブロック研究会」（以降，「会」と略）を立ち上げまし た．目的は，日常の職場ではなかなかできない専門的知識の習得，測定技術向上のための情報提供，情報交換などができ る会の開催とネットワーク構築です。

皆さんにも, 経験が浅い頃, 日々の測定やメンテナンス業務の際, 対応に戸惑った経験がありませんか. 困った際に気 軽に質問できる経験豊富な先輩と知り合い，情報交換できる場が必要と考え自分たちで会を作りました，日々の測定技術 向上に直結できるよう年に数回参集することとなり，現在に至っています（写真 $4 \sim 7$ ).

これまで全国の技術職員の集まる研究会で平成 19 年度機器・分析技術研究会（富山大学）に始まり，近々では平成 28 年度名古屋大学機器・分析技術研究会において会の紹介 ${ }^{2) ~ 9)}$ を行っています. 日本質量分析学会関連では, 平成 21 年第 118 回関西談話会「質量分析技術者の知恵袋」, 平成27年第6回中部談話会「質量分析温故知新～振り返ってみませんか, FAB法とMALDI法〜」において紹介を行いました.

第 1 回終了後, 翌日に私の前任者で当時大阪大学におられた福田氏により作成され, 現在は同大学松崎 剛氏か管理を 行っている会のメーリングリストは，メンバー間の情報交換などに大いに役立っています．当初，会の日帰り開催を念頭

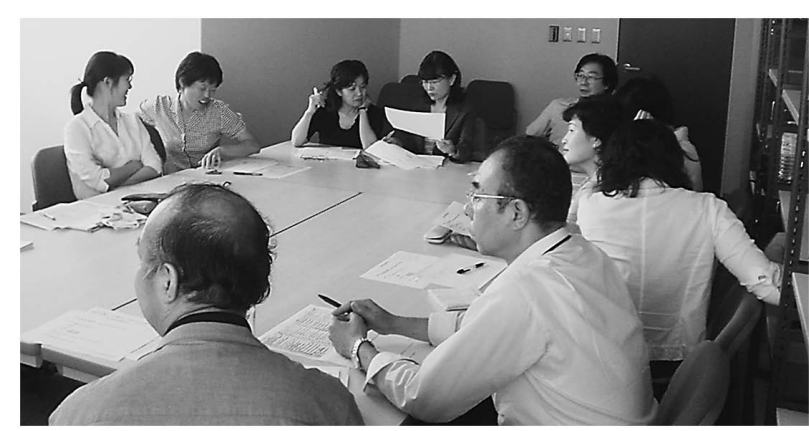

写真 4. 第 1 回研究会 (大阪市立大学杉本キャンパス).

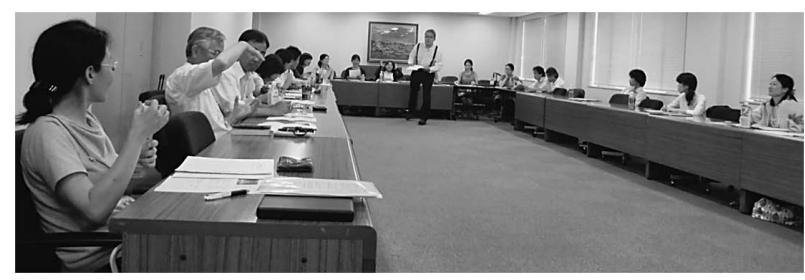

写真5. 第6回研究会 (京都大学吉田キャンパス).

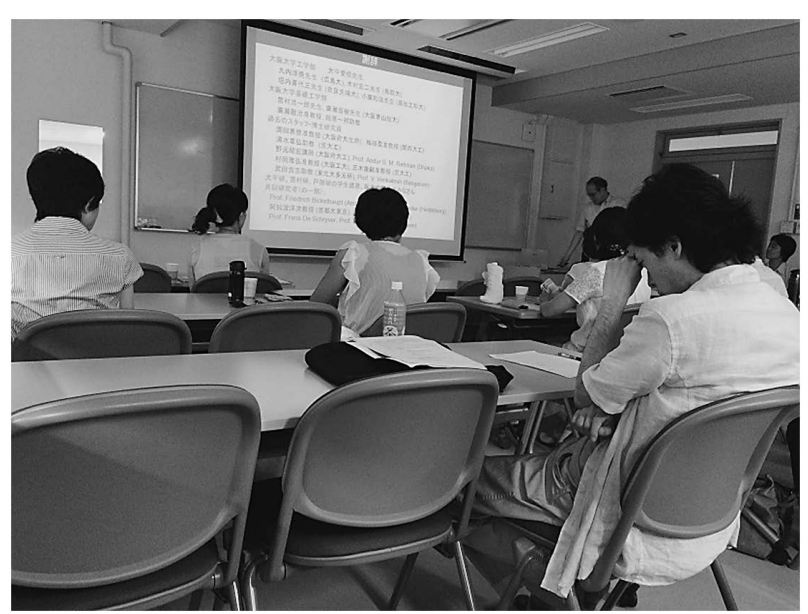

写真6. 第11 回研究会 (大阪大学豊中キャンパス).

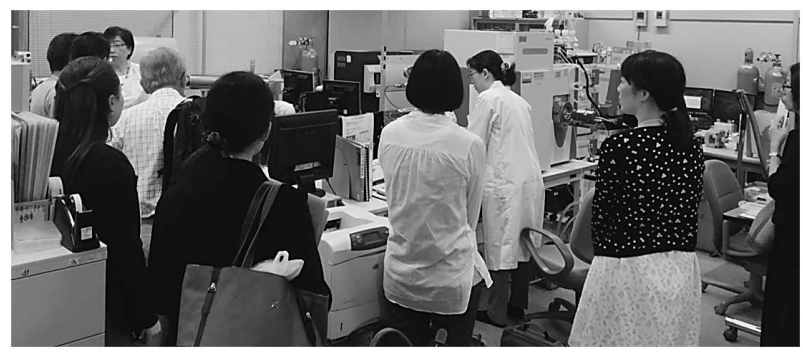

写真7. 第12回研究会 (京都大学桂キャンパス). 

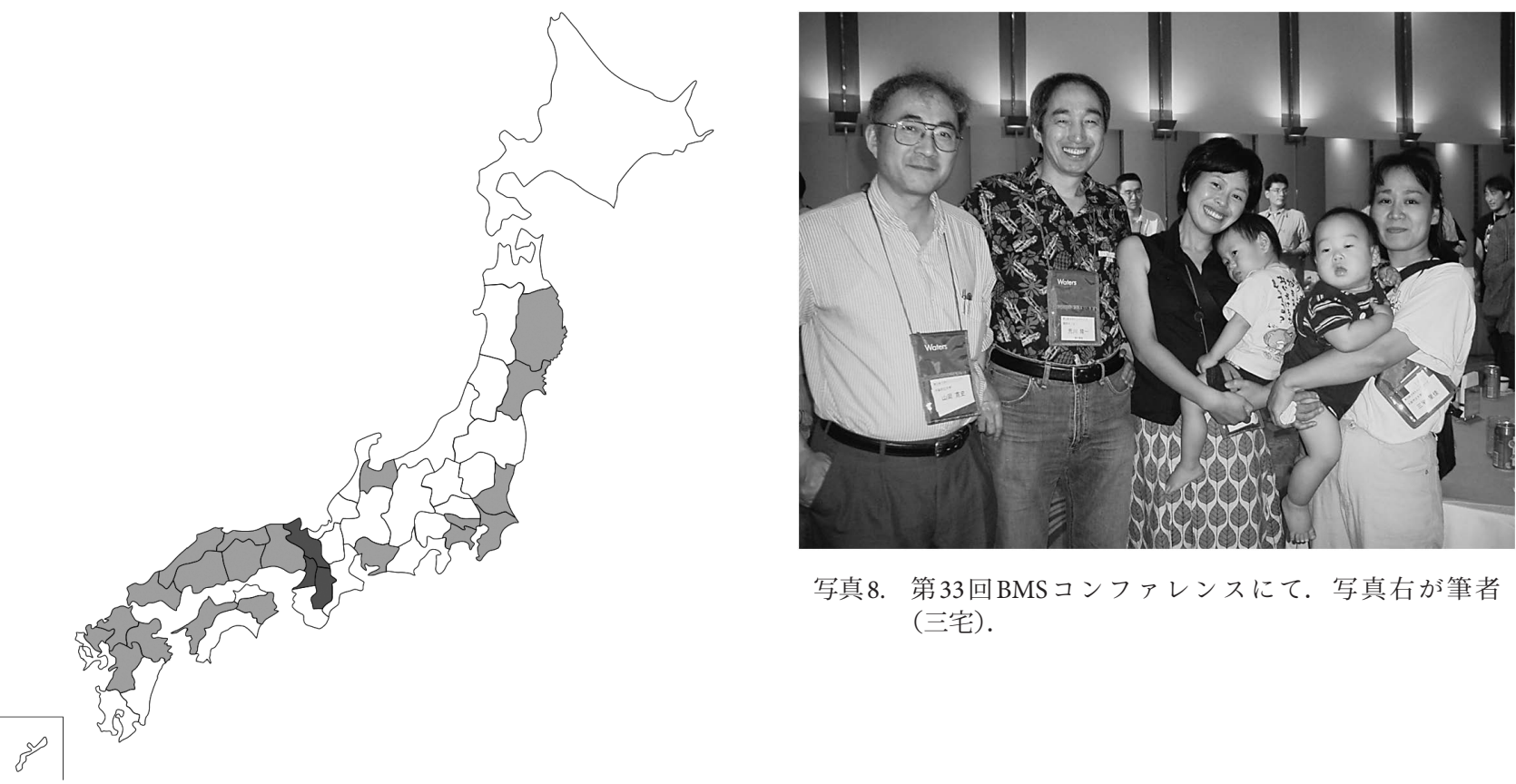

写真 8 . 第33回BMS コンファレンスにて。写真右が筆者 (三宅).

Fig. 3. 質量分析技術者近畿ブロック研究会のメンバーが在 住する府県.

(濃いグレー: 発足当初のメンバー, 淡いグレー：追 加メンバー)

に地域を限っていましたが，メールのやり取りなら距離に関係なく議論ができると考えを改め，また多くのアドバイスを いただけるよう技術職員の枠にとらわれず声をかけ，11年目を迎えた現在では北は岩手から南は熊本まで 78 名（男性 35 名，女性 44名）の登録にまで発展しています（Fig. 3)。「百聞は一見にしかず」で会の参加者同士か顔を合わせての意見 交換や，実地研修は，熟練者の技を間近で見ること，疑問点が瞬時に解決できるなど大きな魅力があります．今後も継続 していきたいと考えていますので，もし，仲間にと考えていただけるなら私までご一報ください，

\section{5. おわりに（三宅里佳）}

私の最初の就職先は恩師に紹介された大阪市立大学です。技術職員となり質量分析にかかわりを持つようになりました. 諸先輩方のノウハウを教わる場として「質量分析技術者近畿ブロック研究会」を立ち上げ，先輩方の技術を少しでも身に 着けるべく必死な時間を過ごしました，それと同時に「じっくりと質量分析を学べる場」と紹介されて参加した「BMS ンファレンス」は，充実した内容や魅力的な参加者の方々に魅かれ，毎年参加していました，が，子育てが始まると参加 を諦めていました，子育て中でも新たな知識を増やしたいとの思いを持つ方がいることを知り，第33回BMS コンファレン スの実行委員・神戸大学バイオシグナル総合研究センターの吉野健一先生に子ども同伴での参加について相談いたしまし た．実行委員会でベビーシッター制度を検討し，初めて実施していただくことができました，子育て中の奈良先端科学技 術大学院大学・西川嘉子氏と共に利用し，久しぶりに参加いたしました（写真8）．参加者の希望を形にしてくださった実 行委員会の先生方のご尽力に改めて感謝申し上げます．現在，ベビーシッター制度も11回を数え，質量分析総合討論会で も提供されています，私自身が利用することはなくなりましたが，今後も制度が続いてほしいと心より願っています。

3 年前, 家庭の事情で家を引越し, 自宅から近い職場を探していたところ, 大阪大学基礎工学部を紹介いただき，転職 いたしました．新天地の環境も雾囲気も大好きになり，心新たに頑張ううと思う日々です．新しいことに挑戦しょうと思 い立ったとき，私が思い浮か心゙る言葉，江戸時代後期，米沢藩主の上杉鷹山公が家臣に教訓として詠んだ歌を記して，終 わりにいたします。

「為せば成る，為さねば成らぬ何事も，成らぬは人の為さぬなりけり」

謝 辞 本稿の作成にあたっては，大阪大学名誉教授の金田清臣先生，元大阪大学技術職員で現在は奈良先端科学技術 大学院大学で技術補佐員をされている福田和夫氏から資料の提供を受けました。ここに謝意を表します。

\section{文献}

1）'99日本電子MSユーザーズミーティング資料，JEOL Application Note MS177.

2）三宅里佳，他，平成19年度機器・分析技術研究会in とやま報告集，93, 2007. 
3）西川嘉子, 他, 第19回生物学技術研究会報告集, P3-27, 2008.

4）三宅里佳，他，平成 20 年度京都大学総合技術研究会報告集，P8-17, 2009.

5）桑田啓子, 他, 平成 22 年度機器 - 分析技術研究会 in 東京工業大学報告集, 3-1, 2010 .

6）三宅里佳，他，平成 22 年度熊本大学総合技術研究会報告集，P8-19, 2011.

7）三宅里佳，他，平成24年度愛媛大学総合技術研究会報告書，P097A, 2012.

8）松崎 剛, 平成26年度北海道大学総合技術研究会報告集, P08-19B, 2014.

9）三宅里佳，平成 28 年度名古屋大学機器・分析技術研究会報告集，37, 2016. 